\title{
GEOTHERMAL ENERGY HEATING AND HOT WATER FOR A DETACHED HOUSE PROJECT IN OVIEDO (SPAIN)
}

\author{
Elena $\mathrm{M}^{\mathrm{a}}$ Fernández Rodríguez ${ }^{\mathrm{a}}$ Eunice Villicaña Ortiz ${ }^{\mathrm{b}}$, Jorge Xiberta Bernat ${ }^{\mathrm{c}}$ \\ Department of Energy \\ E.T.S.I.M.O. Oviedo University \\ 13 Independence Street, $2^{\circ}$ floor. 33004 . Oviedo (Spain) \\ Phone: +34 985104327, e-mail: ${ }^{\mathrm{a}}$ uo182424@uniovi.es, ${ }^{\mathrm{b}}$ uo199857@uniovi.es, ${ }^{\mathrm{c}}$ jxiberta@uniovi.es
}

European Association for the Development of Renewable Energies, Environment and Power Quality (EA4EPQ)

\begin{abstract}
Among renewable energies, geothermal energy is gaining importance due to the different applications that are being accomplished within the residential sector. Forecasts suggest a "promising future" for this energy source.

A study carried out by the Department of Energy at University of Oviedo, approached from technical, economic and environmental views related to this source gave as a result the geothermal installation designed for covering the demand of heating and hot water production (DHW) of a detached house located in Asturias described in this paper. Its aim it's to make an optimal use of geothermal energy, combining a geothermal heat pump with a radiant floor heating system in order to keep the building in comfortable conditions and minimizing the effect of the outside temperature.
\end{abstract}

KEY WORDS: Renewable energies, low temperature geothermal energy, DHW, heat pump, energy efficiency.

\section{Introduction}

Within the framework established in 2007 by the EU when establishing the target of obtaining 20\% of the energy consumed in the year 2020 from renewable sources, followed by the approval in April 2009 of Directive 2009/28/ EC about promotion of the use of renewable energy sources by recognizing the geothermal energy as one of them, this study considers the design of an installation that uses the geothermal gradient to provide heat and hot water to a detached house located in Oviedo (Asturias).

The requirement HE-4, included in the Technical Building Code (CTE by its acronym in Spanish), establishes for Asturias a minimum solar contribution of the $30 \%$. It also indicates that thermosolar energy can be replaced by other renewable energy sources. The European Directive 2009/28 EC declares geothermal energy as renewable and the Institute for the Diversification and Saving of Energy (IDEA by its acronym in Spanish) in its publication
"Comentarios al RITE 2007" indicates that "thermal panel systems can be replaced by other renewable source based techniques if the production of $\mathrm{CO}_{2}$ does not exceed the maximum production permitted by the Administration according to an annual basis". For this reason, the installation described will cover the demand of DHW of the building following what is established in the CTE.

According to Table D1 DB HE1 of the CTE, the house is located in the $\mathrm{C} 1$ climate zone, with an altitude of $214 \mathrm{~m}$. It has three floors: basement, ground and first floor. The installation is designed for heating the ground and first floors completely while, for the basement, only the living room, bathroom and gym are considered.

The proposed system is radiant floor covering a total surface of $320 \mathrm{~m}^{2}$. The house does not have a cooling system and has a thermal insulation of excellent quality, with values of thermal transmittances that surpass the limit values demanded in the DB HE1 document of the CTE. For calculation purposes, it is considered an occupancy of 6 persons in the house, which is the minimum value suggested by the DB HE4 document of the CTE (Section 3.1.1.4) for a house with 4 bedrooms.

The main target in the design of this installation is to provide the user with comfortable environmental conditions by using a heating system characterized for being more energy efficient and less aggressive to the environment that traditional systems.

\section{Geothermal system}

The installation of a heating system applied to housing consists on the heat production elements, the distribution elements, the regulation system and the heat-emitting elements.

The proposed system is based on heat transfer through vertically arranged downhole collectors. A coolant fluid circulates inside the collectors and that acts as a heat 
exchanger, capturing the heat from the ground and transporting it to a geothermal heat pump where it is liberated. At the pump, a low boiling point liquid absorbs heat from the collectors and increases its temperature through a cycle of evaporation and condensation to finally transferring it to the house heating system. Some of the heat is also used for the production of hot water (DHW).

\section{System design.}

\section{A. RADIANT FLOOR}

The basic principle of the system consists of medium temperature water through piping circuits located under the floor of the rooms. Its main feature is that all the surface of the floor acts as an emitter of heat.

In order to determine the dimensions of the heating system, it is necessary to know the surface that will be heated and the heat load required by the entire house including energy losses (expressed in $\mathrm{W}$ ) that the heating system must compensate for maintaining the desired comfortable conditions. To obtain the thermal load there are some aspects to be considered: heat transmission loss $(Q t)$, due to heat loss through the walls or other surfaces, the infiltration and ventilation load $(Q v)$, which is the heat loss derived from infiltration and controlled natural ventilation, and the internal heat gain (Qi), that is negative but it is not considered for the calculations because its magnitude is very small. Thus, the resulting thermal loads for each room $(Q)$, obtained by adding the previous terms, are listed in Table 1.

According to those values, we obtain a heating power of 14 $\mathrm{kW}$ for the building, while the heat demand is $43 \mathrm{~W} / \mathrm{m}^{2}$. From the previous data, we obtain an energy demand of 31 MWh / year.

The building requires the installation of 4 collectors: one collector in the basement for 8 circuits, two collectors in the ground floor (one for 7 circuits and other for 5 circuits) and one collector on the first floor for 10 circuits. They should be located centered on the heating area and higher than the distribution circuits to help purging them.

To calculate the distribution elements, it is necessary measuring the distance between the heating areas and the collectors. The maximum length of the emitter circuits is determined by the maximum length of the tube rolls. The separation between tubes should be the same on all the circuits and it is conditioned by the insulating panel tube spacing. However, in areas of greatest heat loss, such as the windows, it is better to decrease the distance between tubes.

The average water temperature in the emitter tubes (Tma) depends on the room thermal demand $(\mathrm{Q})$, the design indoor temperature (Ti) and the heat transfer coefficient (Ka). Due to comfort reasons, this temperature must not exceed $30{ }^{\circ} \mathrm{C}$. The temperature difference between water discharge and the return is fixed at $10^{\circ} \mathrm{C}$. After calculating all circuits, the higher temperature is selected. This provides a discharge temperature of $40.2{ }^{\circ} \mathrm{C}$ and a return one of $30.2{ }^{\circ} \mathrm{C}$ (values obtained from charts provided by manufacturing companies).

\begin{tabular}{|c|c|c|c|c|c|}
\hline ROOM & $\begin{array}{c}\text { Area } \\
\left(\mathbf{m}^{2}\right)\end{array}$ & $\begin{array}{c}\mathbf{Q t} \\
(\mathbf{W})\end{array}$ & $\begin{array}{l}\text { Qv } \\
(W)\end{array}$ & $\begin{array}{c}\mathbf{Q t}+\mathbf{Q v} \\
(\mathrm{W})\end{array}$ & $\begin{array}{c}\mathbf{Q} \\
\left(\mathbf{W} / \mathbf{m}^{2}\right)\end{array}$ \\
\hline $\begin{array}{l}\text { Small } \\
\text { bathroom }\end{array}$ & 4.37 & 303.6 & 0.0 & 303.6 & 69.5 \\
\hline $\begin{array}{l}\text { Living } \\
\text { room }\end{array}$ & 57.17 & 1276.4 & 326.7 & 1603.1 & 28.0 \\
\hline Gym & 28.29 & 977.3 & 326.7 & 1304.1 & 46.1 \\
\hline $\begin{array}{l}\text { Bedroom } \\
1\end{array}$ & 17.19 & 491.0 & 181.5 & 672.5 & 39.1 \\
\hline $\begin{array}{l}\text { Bathroom } \\
1\end{array}$ & 5.68 & 227.1 & 0.0 & 227.1 & 40.0 \\
\hline $\begin{array}{l}\text { Dining } \\
\text { room }\end{array}$ & 69.5 & 2731.4 & 326.7 & 3058.2 & 44.0 \\
\hline Lobby & 14.1 & 986.5 & 179.2 & 1165.6 & 82.7 \\
\hline Kitchen & 33.52 & 1551.7 & 0.0 & 1551.7 & 46.3 \\
\hline $\begin{array}{l}\text { Bedroom } \\
2\end{array}$ & 21.95 & 801.0 & 181.5 & 982.5 & 44.8 \\
\hline $\begin{array}{l}\text { Bathroom } \\
2\end{array}$ & 6.52 & 375.6 & 0.0 & 375.6 & 57.6 \\
\hline $\begin{array}{l}\text { Bedroom } \\
3\end{array}$ & 21.46 & 576.7 & 181.5 & 758.2 & 35.3 \\
\hline $\begin{array}{l}\text { Bathroom } \\
3\end{array}$ & 7.58 & 208.3 & 0.0 & 208.3 & 27.5 \\
\hline $\begin{array}{l}\text { Bedroom } \\
4\end{array}$ & 25.32 & 930.1 & 181.5 & 1111.6 & 43.9 \\
\hline $\begin{array}{l}\text { Bathroom } \\
4\end{array}$ & 8.13 & 437.4 & 0.0 & 437.4 & 53.8 \\
\hline Entrance & 7.42 & & 94.3 & 94.3 & 12.7 \\
\hline TOTAL & 320.78 & & & $13,759.5$ & 42.9 \\
\hline
\end{tabular}

Table 1. Thermal loads (Q)

The water flows through a circuit of radiant floor heating depends on the thermal power emitted, which is considered to have the same value as the heat load (Q), and the temperature difference $\left(10^{\circ} \mathrm{C}\right)$. In $\mathrm{Q}$ we consider the thermal power emitted by each circuit including the one corresponding to the distance from the room to the collector; that is why we need to calculate the actual areas covered by each circuit.

\section{B. DHW DEMAND}

To DHW demand calculus is based on the DB HE4 document of the CTE. Table 3.1 of that document contains the data of the daily DHW demand by kind of installation based on a reference accumulation temperature of $60^{\circ} \mathrm{C}$. For detached houses, the demand is 30 liters DHW per day and per person. In this installation, the accumulation temperature is $45^{\circ} \mathrm{C}$. The corresponding demand for this temperature can be calculated applying this formula:

$$
D(T)=\Sigma_{1}^{12} D i(T)
$$




$$
\operatorname{Di}(\mathrm{T})=\operatorname{Di}\left(60^{\circ} \mathrm{C}\right) \cdot\left(\frac{60-T i}{T-T i}\right)
$$

Where,

D(T) is the annual DHW demand at T temperature of accumulation.

Di ( $\mathbf{T})$ is the DHW demand at $\mathrm{T}$ temperature of accumulation in the month " $\mathrm{i}$ ".

Di $\left(60{ }^{\circ} \mathbf{C}\right)$ is the DHW demand at a temperature of accumulation of $60^{\circ} \mathrm{C}$ in the month "i".

$\mathbf{T}$ is the temperature of the tank.

Ti is the average temperature of cold water in the month "i".

From the values of the temperature of the water supply in Oviedo given in Table G.2-HE1 DB, we get an average need of 43 liters of DHW per day and per person. The DHW requires a power demand of $2 \mathrm{~kW}$.

\section{GEOTHERMAL COLLECTING SYSTEM}

\section{Well drilling}

The collecting system consists in vertical geothermal pipes which extract the energy stored in the ground, each one with a double PE tube circuit were glycol water flows. There tubes act as vertical heat exchangers. Studies related to this kind of systems estimate a geothermal power of $60 \mathrm{~W} / \mathrm{m}$.

As the pump is $14 \mathrm{~kW}$ and its electric power is $3.04 \mathrm{~kW}$, the total length of the wells reaches 183 meters. Due to the fact that wells are normally less than 120 meters deep, the designed installation has two 91 meters wells. Each well has 2 circuits so that the total collecting length amounts to 731 meters.

\section{Geothermal collecting circuit}

The geothermal collecting double circuit ( 2 independent circuits in each well) is composed of polyethylene PN16 PE-100 32x3 pipes of $32 \mathrm{~mm}$ diameter and $3 \mathrm{~mm}$ thick.

\section{Heat transfer fluid}

The heat transfer fluid used is an antifreeze mixture of water with $30 \%$ propylene glycol at a concentration of $50 \%$, which is nontoxic, ecological and its freezing temperature is $-15^{\circ} \mathrm{C}$. Based on the diameter and length of the collecting tube we obtain a total requirement of 587 liters of, and a propylene glycol requirement of 176 liters.

\section{Primary hidraulic circuit}

The primary circuit has a temperature difference of $3{ }^{\circ} \mathrm{C}$, and a flow of $2.3 \mathrm{~m}^{3} / \mathrm{h}$ of fluid at a theoretical speed of $0.5 \mathrm{~m} / \mathrm{s}$ (to avoid noise). The tubes have a diameter of 40 $\mathrm{mm}$ and 10 long meters, which means 13 liters of water, making a total of 600 liters contained in the collecting system. This circuit has a PN16 PE-100 40x6.8 collector with a diameter of $40 \mathrm{~mm}$ and $6.8 \mathrm{~mm}$ thick.

\section{GENERATION SYSTEM}

The ground accumulates large amounts of energy but its temperature is lower than the temperature of the building. That is why it is require the use of a heat pump.

\section{Secondary circuit}

For the secondary circuit, it is better to use high density polyethylene, PE-100, tubes according with the UNE EN ISO 12241 , with a diameter of $32 \mathrm{~mm}$, a length of 10 meters and thermal insulation of $25 \mathrm{~mm}$ thick.

The temperature difference in this circuit is $8{ }^{\circ} \mathrm{C}$. It has a water flow of $1.09 \mathrm{~m}^{3} / \mathrm{h}$ at $0.5 \mathrm{~m} / \mathrm{s}$. According to UNE 100155 , the expansion tank should have a volume of 8 liters.

\section{Geothermal heat pump}

The system has a geothermal heat pump equipped with a compressor that assures high performance and low cost. The refrigerant used is $\mathrm{R} 407 \mathrm{c}$. The installed pump has a heat output of $14 \mathrm{~kW}$, a COP of 4.6, and consumes 3.04 $\mathrm{kW}$ and with. From this data and knowing the thermal heating demand (31 MWh /year), we obtain an annual electricity consumption of 7 MWh (energy demand/COP). Therefore, the primary thermal energy consumption is $18 \mathrm{MWh} /$ year with a $43.5 \%$ contribution of renewable energy.

\section{Buffer}

A buffer tank is required for regulating the temperature. The system incorporates a steel tank insulated with ST 37 rigid polyurethane foam with an accumulation of at least 300 liters.

\section{Hot water tank}

The DHW tank uses the water of the returning radiant floor circuit to obtain water at the required temperature. This is the reason why the installation of a second deposit of 300 liters is needed.

Finally, Figure 1 shows the diagram of the designed installation for heating and DHW. 


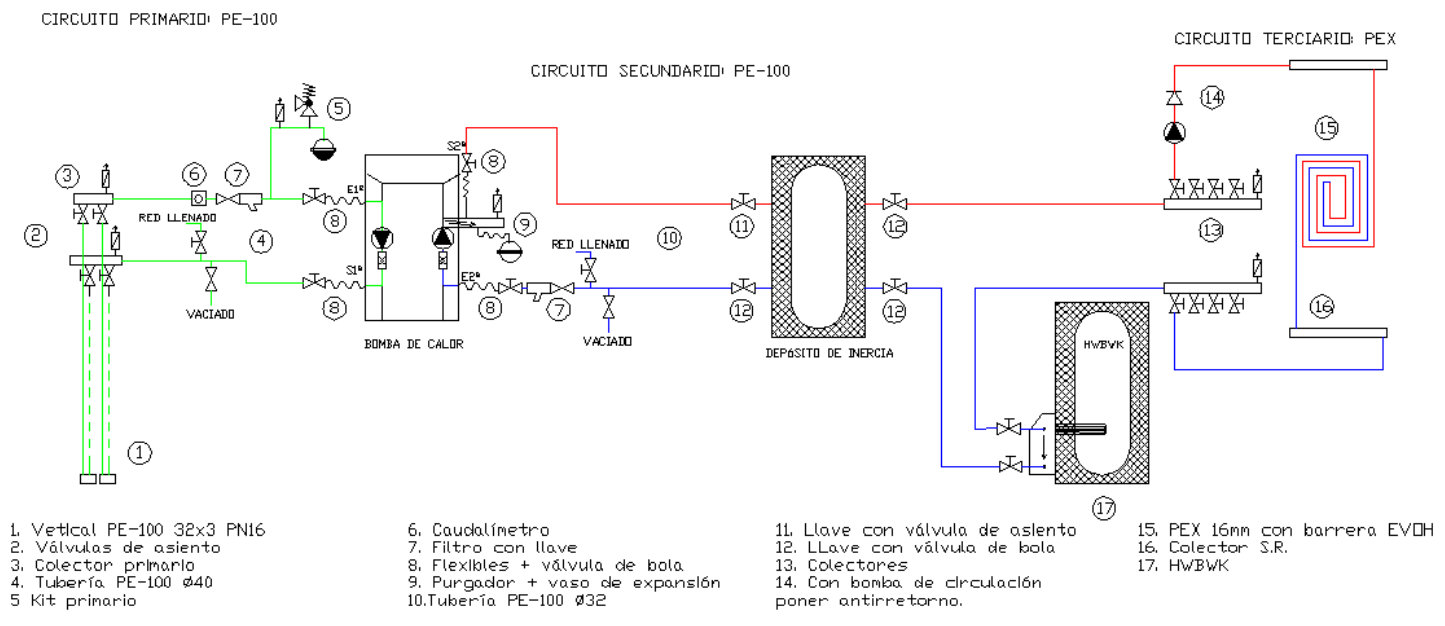

Figure 1. Installation Diagram

\section{Economic evaluation}

The dimensioning of the geothermal system should balance energy conservation and economic cost. It would not be appropriate for the investment to be disproportionate compared to the energy savings achieved and, therefore, not being recovered in a reasonable time. The designed system has two interrelated systems, the geothermal and the radiant floor. The cost contribution of each one of them to the entire installation is shown in Table 2.

\begin{tabular}{|l|c|c|}
\hline DISTRIBUTION & $€$ & $€ / \mathrm{m}^{2}$ \\
\hline Geothermal & 30,810 & 96 \\
\hline Radiant Floor & $10,881.51$ & 34 \\
\hline
\end{tabular}

Table 2. Costs distribution

Each source of energy has a different cost. (Table 3).

\begin{tabular}{|l|c|}
\hline \multicolumn{1}{|c|}{ HEATING } & $€ / \mathrm{kWh}$ \\
\hline Electricity & 0.114 \\
\hline Diesel & 0.072 \\
\hline Biomass (pellets) & 0.057 \\
\hline Natural Gas & 0.05 \\
\hline Geothermal & 0.029 \\
\hline
\end{tabular}

Table 3. Costs of different energy sources

To determine if the system is profitable, the procedure is to compare the cost of geothermal energy with reference to other fuel costs covering the same energy demand, as diesel with $30 \%$ of DWH with solar panels. (Table 4).

\begin{tabular}{|l|c|c|}
\cline { 2 - 3 } \multicolumn{1}{c|}{} & $€$ & $€ / \mathrm{m}^{2}$ \\
\hline Geothermal & 30,810 & 96 \\
\hline $\begin{array}{l}\text { Diesel+ 30\% DHW } \\
\text { Solar panel }\end{array}$ & 20,607 & 64.2 \\
\hline \multicolumn{2}{|c}{ Table 4. Costs comparison }
\end{tabular}

With this information it is possible to calculate the amortization period, by analyzing the accumulated savings. The investment can be considered interesting if it is amortized in 5 years. In this case, the investment is profitable. At present, geothermal energy is subsidized, so the cost will be lower.

The investment grant will cover up to $30 \%$ of the base cost, which is $1400 € / \mathrm{kW}$ for closed vertical drilling. (Table 5).

\begin{tabular}{|l|c}
\hline Thermal Power & $14 \mathrm{~kW}$ \\
\hline Reference & $1,400 € / \mathrm{kW}$ \\
\hline Subsidal Cost & $19,600 €$ \\
\hline Grant & $30 \%$ \\
\hline Estimate & $5,880 €$ \\
\hline \multicolumn{2}{|c}{ Table 5. Investment grant }
\end{tabular}

After calculating the amortization period for both scenarios (subsidized / unsubsidized) we get as a result a period of 3 years and 5 years, respectively. It means that the system is economically viable and profitable. (Figure 2). 
Economical viability. Inversion recovery

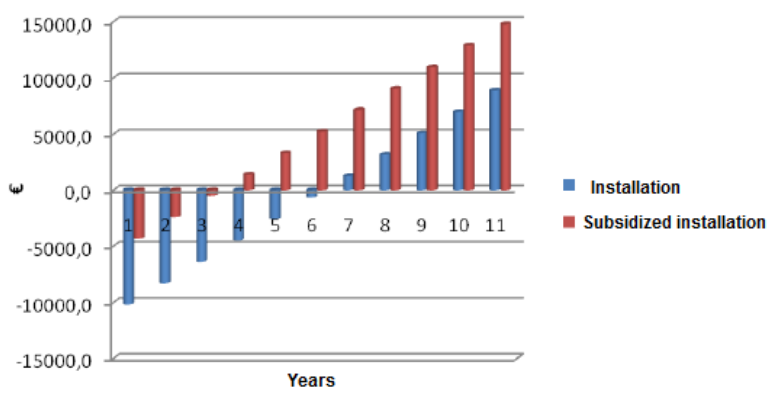

Figure 2. Economical viability. Inversion recovery Source: Author

\section{Balance of emissions}

According to the source of energy used, the emission of greenhouse gases is different. This is reflected in Table 6.

\begin{tabular}{|l|c|}
\hline & $\mathrm{kg} \mathrm{CO}_{2} / \mathrm{kWh}$ \\
\hline Electricity & 0.404 \\
\hline Diesel & 0.287 \\
\hline Natural Gas & 0.204 \\
\hline Geothermal & 0.101 \\
\hline
\end{tabular}

Table 6. $\mathrm{CO}_{2}$ emissions by energy source

The $\mathrm{CO}_{2}$ emissions of the system are calculated based on those values. The result is compared to similar installations based on diesel and Natural Gas. The DHW contribution is similarly calculated. The results of these calculations are shown in Tables 7 and 8.

\begin{tabular}{|l|c|}
\hline HEATING SYSTEM & $\mathrm{t} \mathrm{CO}_{2}$ /year \\
\hline Diesel & 8.9 \\
\hline Natural Gas & 6.3 \\
\hline Geothermal & 2.8 \\
\hline \multicolumn{2}{|c|}{ Table 7. $\mathrm{CO}_{2}$ emissions from heating }
\end{tabular}

\begin{tabular}{|l|c|c|}
\hline DHW & $\mathrm{kg} \mathrm{CO}_{2} / \mathrm{kWh}$ & $\mathrm{kg} \mathrm{CO}_{2} /$ year \\
\hline Diesel & 0.287 & $1,157.7$ \\
\hline Electricity & 0.404 & 407.4 \\
\hline Diesel $+30 \%$ solar & & 810.4 \\
\hline \multicolumn{2}{|c|}{ Table $8 . \mathrm{CO}_{2}$ emissions from DHW }
\end{tabular}

These results show that the use of the proposed system reduces the amount of $\mathrm{CO}_{2}$ emissions. Globally, they produce $3.1 \mathrm{t} /$ year. For the equivalent diesel installation, they would be $10.1 \mathrm{t}$ /year, that is, with this system the emissions can be reduced up to a $68.9 \%$.

\section{Conclussions}

The heat stored in the Earth's surface (thermal inertia) can be exploited by a heat pump for the building heating and DHW production (day and night, winter and summer, and under all weather conditions).

Radiant floor heating is a system that allows users to take advantage of the thermal inertia of the building structure (floor, floors, walls, etc.) to keep a stable temperature inside and enjoy year-round comfort, limiting the influence of the weather conditions outside.

The proposed system is economically profitable despite requiring a bigger initial investment than traditional systems.

The technology used in this project is successful in reducing the level of $\mathrm{CO}_{2}$ emissions by $69 \%$, being 3.1 $\mathrm{t} /$ year the amount emitted in the system compared to $10.1 \mathrm{t} /$ year in a similar diesel installation.

\section{References}

[1] Pons, Jaume y Jutglar Bayeras, Energía Geotérmica. CEAC. ISBN: 978-84-3291-061-6. Barcelona, 2004.

[2] Cano Pina Energía Geotérmica de Baja Temperatura. Editorial CEYSA. ISBN: 978-849696-005-3. Barcelona, 2008.

[3] Conde Lázaro, Eduardo; Ramos Millán, Alberto; Reina Peral, Pablo y Vega Remesal, Ángel. Guía Técnica de Bombas de Calor Geotérmicas. Comunidad de Madrid. ISBN: 978-84-6129-136-6. Madrid, 2009.

[4] Llopis Trillo, Guillermo; López Gimeno, Carlos y Franqueza Palacios, Juan. Guía Técnica de Sondeos Geotérmicos Superficiales. Comunidad de Madrid. ISBN: 978-84-612-9142-7. Madrid, 2009.

[5] Llopis Trillo, Guillermo y Rodrigo Angulo, Vicente Guía de la Energía Geotérmica. Comunidad de Madrid. Madrid, 2009.

[6] La Geothermie. Agence de l'environment et de la maîtrise de l' energie (ADEME), Bureau de recherche géologique et minière (BRGM). ISBN ADEME: 2-86817-786-7/ ISBN BRGM : 27159-0952-7. France, 2004.

[7] Código Técnico de la Edificación. Ministerio de la Vivienda. Real Decreto 314/2006, de 17 de marzo de 2006.

[8] Reglamento de Instalaciones Térmicas en los Edificios (RITE) e instrucciones técnicas complementarias. Real Decreto 1751/98, de 31 de julio de 1998.

[9] Plan de Acción 2008-2012 de la Estrategia de Ahorro y Eficiencia Energética. Ministerio de Industria, Turismo y Comercio. http://www.mityc.es/ (2007).

[10] Planes de Fomento de las Energías Renovables 2005-10 y 2011-20. 
[11] Manual Técnico-Sistema de Calefacción por Suelo Radiante. UPONOR. Madrid, 2009.

[12] www.georenova.com Georenova. [Access: May 2010] 